\title{
REVISTA SEM ASPAS
}

v.7, n.1, jan./jun., 2018

\section{EDITORIAL}

O primeiro número do ano de 2018 da Revista Sem Aspas é composto por nove artigos que abrangem estudos relativos à política latino-americana, ao neoliberalismo, aos autores do pensamento artístico e político no Brasil, à mobilidade populacional e à sociologia do trabalho contemporânea. Os artigos são provenientes do Centro Universitario de Ciencias Sociales y Humanidades da Universidad de Guadalajara (UDG - Jalisco - México), do Programa de Pós-Graduação em Relações Internacionais San Tiago Dantas (UNESP/UNICAMP/PUC São Paulo - Brasil), da Universidade Federal do Estado do Rio de Janeiro (UNIRIO - Rio de Janeiro - Brasil), da Universidade Federal de São Carlos (UFSCAr - São Carlos - Brasil), da Faculdade de Filosofia, Letras e Ciências Humanas da Universidade de São Paulo (FFLCH, USP - São Paulo - Brasil), da Universidade Federal do ABC (UFBAC - Santo André - Brasil) e da Faculdade de Ciências e Letras da Universidade Estadual Paulista (FCL, UNESP Araraquara - Brasil).

Jaime Tamayo e Daniela Iñiguez inauguram o presente número com o artigo intitulado As crises das democracias e as Revoluções das Cores. Os autores cotejam as manifestações políticas que ocorreram no início do século XXI em vários territórios anteriormente comandados pela antiga União Soviética com a ascensão do movimento liderado pelo atual presidente do México, Andrés Manuel López Obrador. O texto contribui para a reflexão sobre as relações estabelecidas entre o modelo neoliberal, a representatividade política, a soberania do Estado-Nação e os centros financeiros internacionais.

Bárbara Carvalho Neves e André Leite Araujo assinam o artigo seguinte, Democracia e as agendas reformistas na América Latina. Alguns aspectos dos projetos de reformas políticas na Bolívia, Brasil, Equador e Venezuela no século XXI são analisados a partir das perspectivas conjunturais daqueles países e das supostas dificuldades encontradas para a realização de projetos políticos que pudessem consolidar efetivamente regimes democráticos naquelas regiões da América Latina. 
A retórica despolitizante da corrupção e a dialética da grande e pequena política: uma narrativa sobre o espetáculo neoliberal é uma reflexão sobre as características assumidas pela retórica do discurso da corrupção na realidade política brasileira do século XXI. Para examinar as limitações impostas por aquela retórica à ação política no contexto do neoliberalismo nacional, Fernanda Abi-Chahin de Oliveira Ferreira utiliza o conceito de hegemonia do filósofo e político italiano Antonio Gramsci (1891-1937) e a teoria da “sociedade do espetáculo" contida na obra do escritor francês Guy Debord (1931-1994).

Conservadorismo Católico na Era Vargas (1930-1945): Liberais, Integralistas e Comunistas segundo Plínio Corrêa de Oliveira é o título do artigo escrito por Moacir Pereira Alencar Júnior. Ao examinar o contexto intelectual em que atuou o intelectual e político católico Plínio Corrêa de Oliveira (1908-1995), o autor descreve as particularidades do pensamento conservador na Era Vargas ao compará-lo com outras correntes de pensamento que se desenvolviam naquela época, nomeadamente o comunismo, o integralismo e o liberalismo.

Otávio Barduzzi Rodrigues da Costa - no artigo intitulado A Arte como Forma de Expressão Social e Religiosidade: Análise Antropológica da Obra Criança Morta - descreve alguns aspectos antropológicos presentes na crítica do pintor brasileiro Candido Portinari (1903-1962) à desigualdade social no Brasil em meados da década dos 40 do século XX.

Modernidade, Brevidade e Catástrofe: Uma Análise do Documentário Nós que aqui estamos por vós esperamos, de Marcelo Masagão é o título do artigo de Rafael Marino. O estudo da obra do cineasta brasileiro Marcelo Masagão objetiva realizar exame imanente e conceitual que possa revelar o sentido da narrativa fílmica contida naquele documentário.

O Patrimonialismo na consolidação do Estado Nacional brasileiro: Os fundamentos da modernização à luz dos conceitos de Raymundo Faoro é artigo assinado por Lucas Barbosa de Santana e expõe aspectos significativos da teoria social e política do jurista e sociólogo gaúcho Raymundo Faoro (1925-2003). A teoria se refere ao processo de desenvolvimento da modernização brasileira e compõe o livro publicado em 1958, Os Donos do Poder: Formação do Patronato Político Brasileiro.

Maíra Darido da Cunha e João Roberto Monteiro da Silva Barbosa são autores do artigo Mobilidade Pendular na Região Metropolitana da Baixada Santista: Uma Análise Comparativa dos Dados Censitários de 2000 e 2010 e propõem a análise dos dados censitários dos referidos anos para caracterizar as porcentagens de mobilidade pendular entre os municípios citados. 
Com o artigo O Culto da Performance: O Novo Modelo de Trabalho no Século XXI, Thiago Alencar Rocha encerra o atual número da Revista Sem Aspas. Ao estudar o conceito de "culto à performance" do sociólogo francês Alain Ehrenberg, o autor realiza investigação comparativa com algumas teorias da sociologia contemporânea concernentes às dinâmicas do mundo do trabalho no século XXI. 